\title{
God and Cogito: Semen Frank on the ontological argument
}

\author{
Paweł Rojek ${ }^{1}$ (1) \\ Published online: 25 April 2019 \\ (c) The Author(s) 2019
}

\begin{abstract}
Semen Frank (1877-1950) was one of the first and most ardent advocates of the ontological argument in the twentieth century. He proposed an original interpretation of the ontological argument based on its analogy to Descartes' Cogito. Frank believed that it is possible to develop Cogito ergo sum into Cogito ergo est ens absolutum. In this paper, I analyze his version of the ontological argument. First, I propose a simple reconstruction of his reasoning, paying attention to its hidden premise. Second, departing from the classical logical interpretations of Descartes' argument, I show that for Frank the claim that God exists had the same logical properties as Cogito. As a result, it seems that his argument was formally correct, though based on a premise which could hardly be convincing for a non-believer. This should not be surprising, however, since Frank, as most Russian religious philosophers, was not interested in the project of philosophical theology. His main concern was rather the development of philosophy based on religious premises, which might be called "theological philosophy".
\end{abstract}

Keywords Semen Frank · Ontological argument · Cogito · Pragmatics · Performatives

The great Russian religious philosopher, Semen L. Frank (1877-1950), confessed, several months before his death, to his son Viktor:

I had one real philosophical revelation. It was in Munich in 1913, when I was writing The Object of Knowledge. I had reached a certain boundary and got into a dead end. I gave up writing and wandered around the room thinking for a whole week. Then there was a flowing of blood to the head, and I decided to leave everything and rest. And then in the night a voice said to me: "Can't you understand a simple thing? Why start from consciousness? Start from being!"

Paweł Rojek

pawel.rojek@uj.edu.pl

1 Institute of Philosophy, Jagiellonian University, Grodzka 52, 33-332 Kraków, Poland 
I said to him: "Sum, ergo cogito", and he replied, "No, rather, Cogito ergo est esse absolutum" (Boobbyer 1995, p. 83-84).

Philip Boobbyer, Frank's biographer, who recalled this story, noticed that "this description of this moment of inspiration provides an excellent setting for the main themes of The Object of Knowledge" (Boobbyer 1995, p. 84). For the main point of Frank's thesis was precisely the transition from the primacy of consciousness, which he called "epistemologism," to the primacy of being, called "ontologism". The transition, however, did not rely on a simple reversal of Descartes' approach, but on its deepening. The proof of the existence of a subject, namely cogito ergo sum, was to be transformed into a proof of the existence of an absolute being, namely cogito ergo est esse absolutum. Hence, the mysterious voice suggested to Frank an idea crucial for his system, namely the new ontological proof for the existence of God.

Frank was one of the greatest defenders of ontological proofs and the precursor of the rebirth of interest in these arguments in the twentieth century. As he admitted himself, "from all the proofs for the existence of God this one has the worst reputation", and "from the times of Kant it is believed to be a sophism whose absurdity and degree of intellectual fraud is almost self-evident" (Frank 1972, p. 110). Despite that, he firmly claimed:

in this doctrine there is no accidental mistake or bizarre fantasy of an errant abstract thought, but an idea which occupied the minds of presumably the deepest thinkers and which constitutes in some sense the main problem and, in our conviction, also the main truth of philosophy (Frank 2000, p. 630).

In a number of his works, Frank propounded a very original interpretation of the ontological argument. Contrary to what he believed, his view was not merely a reconstruction, but rather a creative development of this proof. This new interpretation was apparently offered by a mysterious voice in his dream. Frank noticed that ontological proof, properly understood, shares characteristics with cogito sentences (I shall refer to in this way Cartesian sentences "I think" and "I exist"). For the argumentation of Anselm, as well as that of Descartes, refers to some existential sentences which cannot be reasonably negated. In the case of cogito, it is the existence of thinking subject, while in the case of Ratio Anselmi-the existence of the Absolute. Frank believed that such comparison throws new light on the value of ontological proof. "It seems inconceivable", he wrote about cogito, "that one can acknowledge the certainty of this formula and still renounce the power of ontological proof" (Frank 2000, p. 213). Unfortunately, Frank's original proposition went unnoticed by philosophers dealing with the ontological proof. His most important texts on this issue were written in Russian and not easy accessible. The great contemporary discussion on Anselm's argument, initiated in analytical philosophy soon after Frank's death in works by Norman Malcolm (1960) and Charles Hartshorne (1967), and then continued by David Lewis (1970), Alvin Plantinga (1974) and many others (see Sobel 2004, pp. 29-167; Oppy 2006, pp. 49-96; Szatkowski 2012 for a review of recent debates), has been carried on without taking into account his proposition. This is a pity since Frank outlined a completely alternative way of reading Anselm. 
In this article, I would like to take a closer look at ontological proof as proposed by Frank. I will investigate systematically the analogy indicated by Frank between Anselm's ontological argument and Descartes' cogito. As it happens, cogito ergo sum was the subject of interesting discussions in analytic philosophy, which may be used to analyze cogito ergo est ens absolutum. First, I will analyze various contexts in which the ontological proof appears in Frank's works, and present its dominant interpretation. Then I will turn to two key points in his discussion of the proof: the criticism of Anselm's standard formulation from the second chapter of the Proslogion and the comparison of the ontological argument with Cartesian cogito. The comparison allows an understanding of how Frank reformulated the traditional ontological argument. He pointed out that, assuming that the existence of an absolute being is a necessary condition of the existence of finite beings, the negation of God's existence leads to the same existential and pragmatic contradiction as negating one's own being. The status of the sentence "God exists" is hence similar to the status of the sentence "I exist". However, the consequence of such a reformulation of the ontological argument, which apparently Frank did not realize, is a weakening of the concept of the Absolute. For the existence of God turns out to be not logically, but merely pragmatically, necessary. Frank's argument, as I will undertake to show, is fundamentally correct. Unfortunately, its whole weight lies in the hidden premise, namely a necessary relation of finite beings with the Absolute, the adoption of which may be explicitly regarded as an expression of belief in God.

\section{Frank and the ontological argument}

Semen Frank attended to ontological proof in his works several times, indicating, in turn, its role in the theory of knowledge, tracking its long and intricate history, and analyzing its significance for the philosophy of religion. For the first time, analysis of the ontological proof appears in a chapter of the abovementioned fundamental work The Object of Knowledge published in Russia in 1915 (Frank 2000, pp. 211-218). In general, the study concerns epistemology, and the ontological argument appears in the context of reflections on idealism (Obolevitch 2007). Frank wonders how to leave the sphere of subjectivity. If there were some notions necessarily requiring the existence of their objects, one could infer the existence of something more than only the stream of consciousness. Generally speaking, ontological proofs indicate precisely such notions. "Their point is", says Frank, "can one think of something whose notion would contain its own existence, something whose existence would be logically necessary?" (Frank 2000, p. 211; see also Frank 2000, pp. 547-548). In that broad understanding, it turns out that Cartesian cogito is naturally an ontological argument for the existence of the subject (Frank 2000, p. 589). Another step is the developing of cogito reasoning into the argument for the existence of the Absolute. So, in this way, the paradigm of a philosophy of consciousness is overcome. The fundamental point of the new theory of knowledge is no longer an individual subject (as in Descartes), but the all-encompassing Absolute.

Frank added to his Object of Knowledge a comprehensive supplement, entitled "From the History of the Ontological Argument", published previously as a separate 
text (Frank 2000, pp. 545-630). Dmitrii Chizhevskii, an excellent historian of philosophy, believed this work to be "one of the most significant pieces of historicalphilosophical research in Russian" (Chizhevskii 1954, p. 165). Frank convincingly showed that the history of ontological argument neither began with Anselm nor ended with Kant (Frank 2000, p. 30). He saw the traces of this reasoning as early as Parmenides (Frank 2000, pp. 553-554), he discovered a certain version of the ontological argument for the existence of soul in Plato's Phaedo (pp. 554-562), and found a well-developed proof for the existence of God in Plotinus (pp. 562-566). Frank was one of the first to distinguish clearly between two versions of the argument in the second and third chapters of Anselm's Proslogion (Frank 2000, pp. 574-581), which started to be universally accepted in literature only 50 years after his works. He devoted much attention to the development of ontological argumentation in his favorite philosopher, Nicholas of Cusa (Frank 2000, pp. 581-588). Interestingly enough, Frank treated Descartes' formulation of the ontological proof for God's existence deprecatingly. As he believed, his formulation "did not contribute anything, on the contrary-it impeded showing the persuasive power of this argument" (Frank 1972, p. 134). However, of crucial importance in Frank's version of the proof was its comparison with Cartesian cogito and reference to his theory of infinity (Frank 2000, p. 592). Frank also showed that the famous criticism formulated by Kant had already been in Gaunilo's and Gassendi's writings (Frank 2000, p. 576). Kant's charges, he thought, were rebutted by Hegel, whose version of the proof he nevertheless supposed to be merely a reformulation of Fichte's and Schelling's interpretations (Frank 2000, p. 627, cf. however Rojek 2011). Frank's study, although aimed to endorse his own interpretation, still remains a surprisingly inspiring and broad view of the history of the ontological argument.

Frank returned to the issue of the ontological argument a dozen or so years later in a bulky paper "The Ontological Proof for the Existence of God", presented in 1930 at the Russian emigré Scientific Institute in Belgrade, on the invitation of Peter Struve (Frank 1972). Frank's interesting notes from this period, found in the philosopher's archive in New York, have been published recently (Frank 2017; Obolevitch and Tsygankov 2017). Frank developed his interpretation of the ontological argument and placed it in the new context of the philosophy of religion, up until then his reflections on the proof were mainly grounded in the theory of knowledge (Antonov 2015, pp. 13-14). He pointed out that God, as discovered in the ontological argument, is not an external object but reveals itself directly in the subject. Such a concept of God is much closer to real religious experience than that inspired by the cosmological arguments. As Frank recalled, according to St. John, "The one who keeps God's commands lives in him, and he in them" (1 John 3: 24). Hence, he stated, "this proof is nothing other than a rational recognition of the specific certainty of religious experience" (Frank 1972, p. 151).

In recent years, Frank's ontological argument has finally started to draw the attention of scholars (Kotsiuba 2001; Augustyn 2003, pp. 86-96; Obolevitch and Wszołek 2004; Obolevitch 2006, pp. 193-208; Aliaev 2009; Ehlen 2009, pp. 190-195; Obolevitch and Sajdek 2011; Dobieszewski 2012; Dushin 2014; Obolevitch and Tsygankov 2017). Most typically, Frank's proof is interpreted in the context of his statements relating it to the philosophy of religion, whereas the 
role of this reasoning in his theory of knowledge is usually neglected. Hence, his argument is most often simply taken as an expression of personal religious experience, not as reasoning which can be subject to rational assessment. Vladimir Il'in, one of the first commentators on Frank, wrote that "the life of the ontological argument is a prayer," which is "the life of the Absolute, shining through as a bright flame and bubbling up as a crystal spring" (Il'in 1954, pp. 98, 99). Similarly, Oleg Dushin, the author of one of the most recent studies, wrote that, according to Frank, the basis of the ontological proof is not "simply the extent of logical justification and correctness of rules of reasoning" but rather "the presence of living experience of faith" (Dushin 2014, p. 53). The sense of the ontological proof is interpreted in the same spirit by Teresa Obolevitch and her various collaborators:

This argument is not about discovering the truth about the existence of God, or convincing those who think differently, but merely about expressing it. The argument is only - and as much as - the testimony of faith, and this is where its power, and weakness lie. "Confirmation" that can occur in so-called ontological proof, is of the same nature as mystical experience, and not a rational justification or empirical verification (Obolevitch and Sajdek 2011, p. 185; see also Obolevitch and Wszołek 2004, pp. 43-44; Obolevitch 2006, p. 197, 199; Obolevitch and Tsygankov 2017, p. 107).

I would like to propose a different interpretation of Frank's ontological argument, by developing his remarks formulated in an epistemological, not religious context. My aim is to show that it is not only an expression of his religious intuitions, but also an original rational argument. Frank's proof seems formally correct, though based on a premise which cannot be accepted by someone who does not acknowledge the existence of God. Eventually, indeed, it may turn out that Frank's argument cannot be used to convince "those who think differently", but it is not like that because it is merely a non-discursive report from his personal mystical experience.

Let me briefly summarize key ideas of Frank's ontological proof. In all his statements on this issue, Frank returned to two fundamental thoughts. The first indicated what the ontological argument is not, while the second explained its proper sense. For example, in the article "The Ontological Proof for the Existence of God" he wrote:

The sense of the ontological argument is not that through analysis of some abstract idea, not having a necessary relation with reality, through some "magical" reasoning or logical trick, we reach the statement of reality of its object (Frank 1972, p. 115).

This negative thesis was related to Frank's constantly repeated criticism of Anselm's formulation from the second chapter of Proslogion, which he believed to be source of most misunderstandings of ontological argument. Shortly after that, Frank formulated a positive thesis:

The sense of this argument lies in that from the beginning we have here not an abstract idea but the very fullness of reality, and looking at it we see that 
otherwise we could not have this subject at all, i.e. that here we cannot carry out a normal logical differentiation between an "idea" and its "reality" (Frank 1972, p. 115).

This thesis was illustrated with reference to the cogito argument from Descartes' second meditation. Similar formulations may be found in all places in which Frank spoke of the ontological proof (Frank 2000, pp. 216, 624-625; Frank 1983, pp. 216-17). In the next sections of this paper I will deal with these two theses. First, I will look at his criticism of Anselm's reasoning, and then his analysis of Cartesian argumentation.

\section{Anselm's argument}

Frank criticised the popular version of ontological argument very harshly. In his opinion, "the true meaning" of the ontological argument has been "essentially distorted by all his foes and critics" (Frank 1983, p. 216). Frank thought that the source of these distortions was the first unfortunate formulation of the argument, presented in the second chapter of Anselm's Proslogion. However, as he stated:

This failed form of reflection, which was taken over by his supporters as well as opponents, then repeated by Descartes, and until now remains a favorite object of mocking and training in logical quickness, does not correspond with the essence of Anselm's thought at all (Frank 2000, p. 578).

The second version of the argument, presented by Anselm in the third chapter of Proslogion, and even better in reply to criticism of Gaunilion, is, according to Frank, much more adequate. The comparison of both versions of Anselm's argument reveals, as I believe, how Frank himself understood the very nature of ontological proof.

In the first version of his proof, Anselm hypothetically assumed the existence of an empty concept of God and concluded that it would be contradictory. He wrote in Proslogion II:

Now we believe that you are something than which nothing greater can be thought. So can it be that no such nature exists, since "The fool has said in his heart, 'There is no God"'? But when this same fool hears me... he surely understands what he hears; and what he understands exists in his understanding, even if he does not understand that it exists [in reality]... And surely that than which a greater cannot be thought cannot exist only in the understanding. For if it exists only in the understanding, it can be thought to exist in reality as well, which is greater (Anselm 2007, pp. 81-82).

According to Frank, this is a hopeless attempt "to draw the reality of a thing from the very concept", namely "of transforming in some magical way the originally only assumed, imagined content of a thought into apodictically certain existence of its object" (Frank 2000, p. 215). However, as he says, "it is obvious that, from the content of a thought, abstract from any reference to being, being itself can by no means 
be extracted" (Frank 2000, p. 215). In that situation, acknowledging the reality of a thing becomes a "logical leap" and thus "an elementary logical mistake" (Frank 1972 , p. 114). Hence, the ontological argument in this version is "unjustified" (Frank 2000, p. 215) and "obviously groundless" (Frank 1972, p. 111).

I do not think this criticism of Frank is justified. It seems to me that he does not see clearly enough that the first argument of Anselm is an indirect proof. For Anselm assumes first the existence of God in mind only, and then shows that such a concept is contradictory. Therefore, criticism of the hypothesis rejected by Anselm is completely ineffective. Frank's misunderstanding of the logical character of the first argument can be best seen when he accuses it of contradiction: "naturally, it is not hard to notice that in this form the proof is internally contradictory" (Frank 2000 , p. 575); and in another place: "the reasoning is internally inconsistent and hence unjustified" (Frank 1972, p. 124). Obviously, it can be no other way since this is explicitly an indirect proof. The contradiction at which Anselm arrives proves precisely that God cannot be only a conceived being.

According to Frank, a much better formulation of ontological argument is presented in Proslogion III:

This [something than which nothing greater can be thought-P. R.] exists so truly that it cannot even be thought not to exist. For it is possible to think that something exists that cannot be thought not to exist, and such a being is greater than one that can be thought not to exist... So that than which a greater cannot be thought exists so truly that it cannot even be thought not to exist (Anselm 2007, p. 72)

Frank commented on the second version of the Anselm's argument in the following way:

At first sight it is hard to notice a crucial difference between this form of argument and that presented above; yet, the difference occurs indeed, in that the reflection does not at all start with the concept of God as only conceived, in order to subsequently derive from it his necessary being, but rather starts with the statement that the concept of God as the absolute maximum cannot be conceived otherwise as encompassing in itself the real existence of God (Frank 200, pp. 578-579).

In other words, there is no assumption of the indirect proof which caused Frank's unease, namely that one can think of something that in fact cannot be thought of. To Frank, Anselm's wording from the first chapter was only "a psychological and didactic means" (Frank 2000, p. 580) that had to facilitate grasping the main idea presented in the third chapter, namely "the contradiction of a hypothetical concept of God" (ibid.). For the fundamental intuition of the ontological argument is that there "are things... which are given to our thought in such a way that their very reality is given to us immediately and necessarily" (Frank 1972, p. 115).

According to some commentators, Frank was the first philosopher who distinguished the two versions of Anselm's ontological proof, a distinction which was later independently discovered by Malcom and Hartshorne and widely accepted in 
the literature (Obolevitch and Tsygankov 2017, p. 110). It seems however that the grounds for these distinctions were quite different. While Frank considered the second argument merely a more adequate version of the first form, Malcolm and Hartshorne saw there a fundamentally new concept of God as a necessary being. Such being is either impossible, or necessary, and since it is possible, it exists (Malcolm 1960; Hartshorne 1967). No such claim can be found in Frank's version. For this reason, it is hard to recognize that he in any way anticipated later discussions of the ontological argument in analytical philosophy. His thinking went in a completely different direction. He did not analyze - as I will show later-the necessity of the existence of God in itself, but rather pointed to the necessary relation of the thinking subject to God. For this reason, Frank's version seems to be an original and unique development of the ontological argument.

\section{Cartesian Cogito}

Frank's most original idea was a positive attempt to explain the nature of the ontological argument. He wrote:

In order to understand the sense of this statement and notice at least its possibility, let us turn to... argumentation, which at first sight has nothing in common with ontological proof for the existence of God, and which enjoys very widespread recognition as a paradigm of a logically self-evident thesis. I mean here cogito ergo sum by Descartes (Frank 1972, p. 115).

For Frank, then, Cartesian cogito was to be an explanation of ontological proof. Besides, Frank believed cogito itself to be a kind of version of ontological proof, as in his opinion this concept was not limited only to arguments for God's existence (Frank 2000, pp. 547-548). What were the ontological arguments to be then?

An ontological argument claims that being is not always something alien to an idea and belonging to it externally. On the contrary, there are some points in which being and thinking merge, unite directly and inevitably. It points to the presence of the contents of thought, whose meaning essentially transcends the boundaries of their content, in which, on the contrary, being appears directly, if one may say so, it shows through. Such are the concepts of being and consciousness, such is also the concept of God, because God is understood as the primary foundation and bearer of being and reason (Frank 2000, p. 217, italics mine).

The very existence of the concepts that can serve as the basis for ontological arguments would be impossible if the objects to which they refer did not exist. Acknowledgement of their presence is thus simultaneously acknowledgement of the existence of their designates. Frank indicated in this respect three concepts: being, consciousness and God. Cartesian cogito is an ontological argument for the existence of consciousness and being, while Ratio Anslemi is an ontological argument 
for the existence of God. As it will turn out, Frank believed they virtually form one comprehensive argument.

Cartesian reasoning in the second meditation, like the first version of Anselm's argument, has the form of indirect proof. Descartes assumes that he is in the power of an omnipotent deceiver, but it turns out that even under such circumstances he cannot doubt his own thinking and his own existence.

But there is some deceiver or other who is supremely powerful and supremely sly and who is always deliberately deceiving me. Then too there is no doubt that I exist, if he is deceiving me. And let him do his best at deception, he will never bring it about that I am nothing so long as I shall think that I am something. Thus, after everything has been most carefully weighed, it must finally be established that this pronouncement "I am, I exist" is necessarily true every time I utter it or conceive it in my mind (Descartes 2006, p. 13).

Interestingly, this time Frank does not mind the form of Cartesian argument. In The Object of Knowledge he analyzed two forms or two aspects this argument. The first concerned the idea of consciousness, and the second the idea of being. Both can be related to elements of Cartesian cogito ergo sum: the former with cogito, the latter with sum.

First, as Frank pointed out, Descartes discovered that one cannot reasonably doubt the very existence of consciousness. He wrote:

I may negate and doubt any content of my thoughts but not the very thought or consciousness in itself: doubting, itself being a thought, cannot apply to the thought itself. Any attempt at doubting in the existence of thought ascertains it by the very fact of doubting (Frank 2000, pp. 204-205; see also his Frank 1972, p. 120).

Therefore, consciousness cannot be merely a thought. The presence of its idea is at the same time the evidence of its existence. "A thought necessarily becomes aware that it exists, hence a thought merely being thought is internally contradictory... it is a typical ontological proof" (Frank 2000, p. 590).

Second, the very idea of being has the same exceptional logical feature. Thinking that there is no being is as contradictory as thinking that there is no thought, for the very thought is a being.

One may reasonably question whether there exists some particular idea because it means asking: Is this idea part of being? However, one may not ask: Does being itself exist? For the thought which is expressed by the question "Does exist...?", itself presupposes this being (Frank 1972, p. 120; see also Frank 2000, p. 205). ${ }^{1}$

As Frank remarked, so we discover that being is not something external to the thinking subject. As he wrote, "the great illuminating sense" of cogito is that

\footnotetext{
1 I disregard here another Frank's formulation of ontological proof for the existence of being, which seems plainly incorrect to me (Frank 2000, p. 213).
} 
there is a being which is not given through consciousness but reveals itself "completely directly, a being, which we know precisely because we are it ourselves" (Frank 2000, p. 205). Frank, however, was very cautious as regards to defining the status of this being. He agreed with Lichtenberg's criticism, essentially repeated by Solov'ev, that Descartes could at most prove the existence of a thought and not the subject of the thought (Lichtenberg 2012, p. 152; Solov'ev 1988, pp. 781-782). As Frank wrote, cogito ergo sum should hence be weakened to cogito ergo est cogitatio (Frank 2000, p. 204). In each case, however, the existence of something is stated, regardless of its being only an idea in mind or a thinking subject. This suffices to pass from a thought to a being. "At least in one little sphere, in our consciousness, we have being not only for consciousness but also really existing" (Frank 2000, p. 205).

Frank believed that these two "ontological arguments" avoid the standard criticism that applies to the argument for the existence of God. According to Kant's classic objection, every idea may be thought as non-existing. However, to Frank, the concepts of consciousness and being were the exceptions of this rule, for the very possibility of thinking them proves that they are not merely ideas.

It would be unreasonable to say that being and consciousness are concepts only... On the contrary, they are examples of such ideas which are inseparable from the thought about the existence of their objects, and more precisely - such concepts for which the distinction between "an idea only" and "the real existence of the object" makes no sense (Frank 2000, p. 214; see also Frank 1972, p. 116).

Frank thought that ontological proof in the strict sense, namely an argument for the existence of God, has the same nature as the Cartesian arguments for the existence of consciousness and being. As in the case of consciousness and being, one cannot have the idea of God if God does not exist.

When reflecting on what we understand when we think of an idea of the Absolute we become convinced with direct self-evidence that any negations or doubts towards it are simply impossible and pointless, and thus it has necessary existence (Frank 2000, p. 581).

However, the necessity of God's existence does not follow-as it is usually thought, both by supporters and critics of the ontological argument-from the very content of the idea of God, who presumably is to be a necessary being, but rather from the very act of having the idea of God, which necessarily requires God to exist. It is not a logical necessity in a strict sense but rather a pragmatic one. The concept of God, therefore, is supposed to have a similar nature as the concepts of consciousness or being. One cannot have them if there are no objects to which they refer. Thanks to this modification, Frank's argument avoids classic charges leveled by Gaunilon, Gassendi or Kant. I think that Frank's proposition is in fact a new version of the traditional ontological argument. Anselm's argument is reformulated here following the pattern of Cartesian reasoning. Now I will take a closer look at the passage from cogito to ens absolutum. 


\section{Cogito ergo est ens absolutum}

Frank interpreted the Cartesian cogito as an ontological proof for the existence of consciousness and being. As Descartes showed, one cannot think of the concept of consciousness or being as not having their objects, for the very fact of thinking them proves that one is conscious and hence that something exists. Frank believed that this pertains to the concept of God as well, namely that the Cartesian position is only a step from an ontological argument for the existence of God. "A detailed analysis of Cartesian cogito, ergo sum shows", he wrote, "that this claim turns into truth: Cogito, ergo est esse absolutum" (Frank 1972, p. 120). It is noteworthy that this is the sentence that the mysterious voices suggested to Frank in his dream.

However, this passage, crucial in all Frank's philosophy, seems quite unclear. In many places, Frank affirmed that in the very act of cogito not only individual consciousness and finite being are revealed but also the Absolute itself.

What the ontological argument expressed in the Cartesian formula cogito ergo sum applies to is neither "my individual I" nor even "I in general" or "epistemological subject," but the Absolute as such (Frank 1972, p. 119).

Clearly, the Absolute was understood by Frank not epistemologically as a being above the distinction between subject and object, which could be accepted, but metaphysically, as "absolute life, so to say an alive trembling of the deepest primitive source of all which can be thought and which exists" (Frank 1972, p. 119). Surprisingly enough, many commentators regard this highly controversial passage as quite natural. Giennadii Aliaev, for instance, states:

Cogito is a self-revelation of reality, but not the reality of "I" as a subject, inevitably limited and relative, but the absolute reality in which the act of thinking and its content merge into one. In this way, cogito really becomes ontological proof for the existence of Absolute as such, namely God (Aliaev 2009, p. 156).

Similarly, Peter Ehlen simply ascertains that "what Descartes proves by the $\operatorname{cog}$ ito formulation is not the existence of separate I but an Absolute being as such" (Ehlen 2009, p. 192). Despite this, it seems that the direct passage from cogito to esse absolutum is plainly unjustified. It is simply not clear how cogito experience may indeed reveal the Absolute.

Yet, in Frank's works, an attempt at a justification and clarification of this passage can be found. He pointed out that the notions of consciousness and being, the fundaments of the Cartesian cogito, are specially related to the concept of God, which is relevant in the ontological argument. For, as he wrote, "God is understood as the original foundation and bearer of being and reason" (Frank 2000, p. 217, italics mine). If God is the foundation of being and consciousness, then maybe their concepts are necessarily connected with the concept of God. If that was the case, the transition from cogito to ens absolutum would be somehow justified. Frank developed this idea by analyzing further statements of Descartes 
from Meditations. As already mentioned, he was not interested in the proper Cartesian argument for the existence of God from the fifth meditation, which he believed to be faultily presented (Descartes 2006, pp. 36-39; Frank 1972, pp. 133-134). However, Frank was very enthusiastic about the argument for God's existence from infinity in the third meditation, in which he saw "admirable, deep intuition," (Frank 2000, p. 592) which was "an essential moment of the real ontological proof” (Frank 1972, p. 134). Descartes wrote:

Nor should I think that I do not perceive the infinite by means of a true idea, but only through a negation of the finite... On the contrary, I clearly understand that... the perception of the infinite is somehow prior in me to the perception of the finite, that is, my perception of God is prior to my perception of myself (Descartes 2006, p. 25).

In other words, to Descartes the concept of a finite being is secondary to concept of an infinite being, and hence the concept of a finite subject presupposes the concept of Absolute. As Frank wrote:

By virtue of these remarks it becomes clear that what is primarily and directly given to us is not "our consciousness" but the idea of infinite being. Descartes did not draw the natural conclusion from this that thereby we have the one and only real ontological argument for the existence of God, and that cogito, ergo sum would fundamentally have to be transformed after these explications into cogito, ergo est ens infinitum (Frank 2000, pp. 594-595).

In this way, thanks to Descartes' findings, his cogito may be improved and developed into an ontological argument for God's existence. Cogito alone appears to be only "the first step... towards realising the original self-evidence of infinite being, namely God" (Frank 1972, p. 136). The missing premise of the reasoning is the necessary relation of a finite and accidental being with an infinite and necessary one. Therefore, it looks like Frank's ontological argument for God's existence is just a strengthened version of Cartesian cogito. It relies on noticing that one cannot negate the existence of one's own finite being and that the existence of finite being presupposes the existence of the Absolute. In this way, the existence of God is as selfevident as the existence of our own selves.

Let me try to reconstruct this cogito ergo est ens absolutum argument. It seems that it has two separate premises:

(1) I exist,

(2) $\square$ (If I exist, God exists),

from which, by modus ponens, plainly follows the conclusion:

(3) God exists.

Premise (1) is a part of Cartesian cogito. One could obviously start also with "I think", but "I exist" simplifies the proof and has the same epistemological status 
as "I think". This status, as I will show, is passed down to the conclusion of the argument.

Premise (2) is crucial to the whole proof. It expresses intuition that the existence of a finite being is conditioned by the existence of an infinite being. God is an Absolute being, the ultimate source of existence for everything else. If there were no God, there would be no anything. Especially, there would not be finite subjects reflecting upon God's being. This is particularly evident in contraposition (2):

\section{(If God does not exist, then I do not exist.)}

Cartesian reflection on infinity was aimed to express precisely this intuition. This formula however grasps Frank's even more general and fundamental conviction that the world is essentially dependent on God. Hence, formula (2) expresses a basic religious insight on the contingency of all things and the necessity of God. For this reason, it seems doubtful whether it could be accepted by someone who does not accept the existence of God. For Frank's argument, the most important is that, on religious grounds, the existence of God turns out to be as undeniable as the existence of our own selves.

Conclusion (3) and premise (2), as they stand, concern God, though perhaps they should refer to a more abstract Absolute. What is meant here is the being which is the source of other beings. The relation of this philosophical Absolute to the God of religion is a separate problem, which Frank considered the greatest problem of his ontological proof (Frank 1972), and which I will not address here (Zelinsky 2015).

The passage from (1) to (3) is formally correct. It is worth noticing that, although premise (2) is necessary, the very conclusion of the argument, according to the rules of modal logic, is not necessary because premise (1) is not necessary. However, the latter is undeniable, hence the conclusion may be regarded as evident as well.

Frank's ontological argument in such formulation unexpectedly proves to be a specific combination of Ratio Anselmi, Cartesian cogito and, for instance, the Third Way of St. Thomas Aquinas. Indeed, premise (2) may be viewed as an expression of classic intuition that an accidental being requires a necessary being for its existence (ST I, 2, 3c). However, while the starting point for Aquinas could be any accidental being, for Frank it was a particular being of the thinking "I". This starting point is the only trace of the ontological nature of the argument, for its beginning is a concept which cannot be empty, or rather a sentence in whose truth one cannot reasonably doubt. However, cogito serves here only to strengthen premise (1), which seems to be the strongest link of the whole argument. Frank's argument is based on premise (2), which is adopted without any discussion. In Aquinas, for instance, it was a subject of a separate, quite complex (and also incorrect) proof (Bochenski 2000, pp. 77-81).

The most striking thing in Frank's ontological proof is that the conclusion has the same specific epistemological status as its first premise. The sentence "I 
exist" is true whenever someone says it. This makes up the compelling power of Cartesian cogito, which is universally accepted as undeniable. Now I will show that, on the grounds of the adopted premise (2), the conclusion "God exists" has the same distinguished status. Hence, Frank was right when he claimed that if one acknowledges the obviousness of cogito, then one should also acknowledge his argument for God's existence (provided that, naturally, one also accepts the hidden premise just analyzed). For one cannot reasonably deny God's existence. If God did not exist, there would be no one to reflect on such a matter. Stating God's existence is therefore of similar status as stating one's own existence. To show this precisely, I will first examine the logical peculiarities of the sentence "I exist", and subsequently, assuming premise (2) without further discussion, in a similar way I will analyze the sentence "God exists".

\section{The analysis of Cogito}

Since the very beginning of analytical philosophy there is a discussion on the peculiar character of the Cartesian cogito (Russell 1905; Scholz 1931; Łukasiewicz 1938; Ayer 1953). The sentence:

\section{(1) I exist}

is particularly problematic to analyze. First, it is a singular existential sentence, and such sentences were not, for a long time, due to Frege's influence, acceptable in analytical philosophy. Second, it contains a personal pronoun, hence it is occasional and its meaning depends on who says the words. Third, an attempt to formalize this sentence in standard logic leads to difficulties because the very use of a proper name presupposes the existence of its designate. Yet, most intriguing is its epistemic status. For sentence (1), although not necessarily true like mathematical or logical truths, in some circumstances cannot be negated without a kind of contradiction. However, as Alfred Ayer (1953, p. 30) noted, it is not a formal contradiction. It is clear when one compares two sentences:

(1') I do not exist,

(1") Descartes does not exist.

Sentence (1') seems contradictory whenever it is spoken by someone. However, when in $\left(1^{\prime}\right)$ the pronoun is replaced with a proper name, like in $\left(1^{\prime \prime}\right)$, this sentence, unless spoken by Descartes, does not lead to any contradiction, and moreover, seems to be true (I ignore here the issue of difficulties of negative singular existential sentences). The same proposition spoken by Descartes would therefore be contradictory, but when spoken by somebody else, is not. This means that the contradiction that arises here is related not with the content of the proposition but with the person who says it.

The turning point in the analytical discussion of cogito was the famous article by Jaakko Hintikka (1962), which formulated a performative interpretation of the 
Cartesian argument. The article triggered discussions that continue today (Weinberg 1962; Nakhnikian 1969; Rapaport 1976; Hintikka 1963; Feldman 1973; Chernaia 1993; Hintikka 2000; Slezak 2010). Once I tried to supplement Hintikka's analysis with the formalization of cogito ergo sum in Leśniewski's ontology (Rojek 2003), but it turned out that the same result had been attained earlier by Eugeniusz Wojciechowski (Wojciechowski 1987). Hintikka tried to explain the source of cogito's indubitability with the concept of existential inconsistency. Slightly modifying his notation, the concept may be defined as follows:

(*) The sentence $p$ is existentially inconsistent for the person $S$ if the sentence $\ulcorner p \wedge$ $S$ exists $\urcorner$ is inconsistent (Hintikka 1962: 11).

The peculiarity of (1) lies therefore in that its negation (1') is existentially inconsistent for the person uttering it. However, sentence ( 1 ") is not inconsistent for the speaking person (unless it is Descartes himself). As can be seen, existential inconsistency is not a property of sentences in themselves, but rather of their relation to people speaking them. Hintikka wrote:

The inconsistency (absurdity) of an existentially inconsistent statement can in a sense be said to be of performatory (performative) character. It depends on an act or "performance", namely on a certain person's act of uttering a sentence...; it does not depend solely on the means used for the purpose, that is, on the sentence which is being uttered (Hintikka 1962, p. 12).

The inconsistency to which negating cogito leads is therefore not a formal one but performative. "The sentence is perfectly correct as a sentence, but the attempt of a certain man to utter it assertively is curiously pointless" (Hintikka 1962, p. 12). Cogito is necessary, not logically, but pragmatically.

Hintikka's interpretation was developed, among others, by George Nakhnikian (1969) and William Rapaport (1976). Nakhinian analyzed in detail three particular properties of cogito propositions: their incorrigibility, self-certification and pragmatic inconsistency to which their negations lead. The latter term was to be a generalisation of existential inconsistency discovered by Hintikka. Rapaport defined, after Nakhinian, pragmatic inconsistency as follows:

(**) Person $S$ is pragmatically inconsistent with respect to proposition $p$ if and only if (i) $S$ asserts that $p$ and (ii) $\square(S$ asserts that $p \supset \neg p$ ) (Nakhnikian 1969: 199; Rapaport 1976: 65).

Both authors extended the concept of pragmatic inconsistency to other propositional acts, especially to recognizing, inferring and doubting, wherewith the last instance, the condition (ii) should be modified to form $\square(S$ doubts that $p \supset p)$. Negating cogito is, naturally, pragmatically inconsistent, for it is necessary that if $S$ believes, doubts or infers, then $S$ exists. If it did not exist, it could not have such acts. This is especially so in the case of asserting that oneself does not exist. If $S$ did not exist, it could not assert it did not exist. Hence, if $S$ thinks it does not 
exist, it contradicts the fact of its existence. The same is true in the case of thinking. For, if someone believes that does not think, he or she falls into pragmatic inconsistency, since that very belief is an act of thinking. It is noteworthy that the concept of pragmatic inconstancy is wider than the concept of an existential one. For example, the sentence "I have no concepts" is not existentially inconsistent because it does not entail my non-existence, but it is pragmatically absurd: if someone thinks they have no ideas, they have some ideas by which they can think this (Nakhnikian 1969: 205). The definition of pragmatic inconsistency (**) also prevails over existential inconsistency $(*)$, because it clearly formulates premise (ii) which is the ground of inconsistency.

The concepts of Hintikka's existential inconsistency and Nakhnikian's pragmatic inconsistency are to explain the sources of the irrefutability of Cartesian cogito. Its sources are not merely the supposed clarity and distinctness of the concept of the thinking subject or being, but rather the situation in which the person utters cogito sentences. Inconsistency is not the result of abstract consideration of the concept's content but of taking pragmatic context into account. The irrefutability of cogito does not follow from their logical necessity, as in the case of mathematical or logical sentences, but precisely from the pragmatic necessity required by everyone who uses language.

The performative nature of cogito, discovered by Hintikka and others, to great extent explains Descartes' own hesitation about its logical status. Sometimes he suggested that it is an inference, and sometimes that it is an insight. "It is not the case when someone says 'I think, therefore I am, or I exist'—wrote Descartesthat he is deducing existence from thought by means of a syllogism; rather he is recognizing it as something self-evident by a simple intuition of the mind" (Descartes 2006, p. 83). Likewise, Frank believed that cogito is not an inference but rather a "direct perception of the self-evident connection of being and the possibility of being thought, existence and essence applied to the notion of cogitatio" (Frank 2000, p. 590). This is so because the impossibility of thinking one's own non-existence does not follow from its inconsistency with some sentences, which could be logically proven, but from the pragmatic inconsistency with one's own existence, to which we have direct access.

\section{Analysis of Est ens absolutum}

Now I will show that, if premise (2) is accepted, then all the above-mentioned logical characteristics of cogito apply also to the sentence

\section{(3) God exists.}

It is so because the negation of this sentence, namely

(3') God does not exist, 
is, on the ground of (2), existentially and pragmatically inconsistent for any subject who utters it. Acknowledging the existence of God is therefore as evident as acknowledging one's own existence. I believe that it is precisely this observation that contains the essence of Frank's ontological argument for the existence of God.

First, the conjunction of the sentences "God does not exist" and " $S$ exists" is as inconsistent as the conjunction of " $S$ does not exist" and " $S$ exists". This is so because, from ( $\left.3^{\prime}\right)$ and (2), or rather (2'), it follows directly that $S$ does not exist. If God does not exist, there are no other subjects, especially the one who reflects on it. Hence, if one claims God does not exist, they undermine their own existence. Therefore, $\left(3^{\prime}\right)$ is existentially inconsistent in the sense of Hintikka for any subject $S$.

Second, sentence $\left(3^{\prime}\right)$ is also pragmatically inconsistent in the sense of Nakhnikian, meaning that it follows from the fact of one having some convictions that they are untrue. Let us assume that $S$ believes that God does not exist. Since $S$ has some opinion, it follows that $S$ exists. It further follows from the fact that $S$ exists, by the virtue of (2), that God exists. In other words, if $S$ believes that ( $\left.3^{\prime}\right)$, then at the same time, from the fact that they believe $\left(3^{\prime}\right)$ it follows that $\left(3^{\prime}\right)$ is not true. Sentence $\left(3^{\prime}\right)$ is therefore pragmatically inconsistent for any $S$.

The difference between existential and pragmatic inconsistency in the case of Descartes' cogito and Frank's ontological argument lies in a fact that Frank presupposes an additional, non-logical premise (2). Therefore, his argument, in contrast to Cartesian one, is not purely pragmatic; it relies on a grave metaphysical premise. Nevertheless, it draws its persuasiveness (if it is persuasive at all) from the same pragmatic sources as cogito.

Thus, it turns out that Frank's argument cogito ergo est ens absolutum starts with indubitable cogito and ends with likewise indubitable Est ens absolutum. God's existence, still provided that one accepts the assumption (2), is as obvious as one's own existence. An attempt to think that God does not exist leads to the same result as an attempt to think that "I" do not exist, i.e. to the existential and pragmatic inconsistencies described by analytical philosophers. So Frank was generally right in that his ontological proof has a similar logical status as cogito.

This likeness is also revealed in Frank's uncertainness about the nature of his version of ontological argument. Like Descartes, Frank sometimes suggested that this argument has some steps (Frank 1972, p. 136), most often, however, he stated that it is a simple intuitive insight. He wrote:

If one understands an "argument" as a movement of thoughts consisting in reasoning and explaining some truth in an indirect manner, thanks to establishing its relations with other truths, then ontological argument is not an argument at all; on the contrary, it is a movement of thoughts which leads to direct perception of primary, self-evident truth (Frank 1972, p. 120, see also pp. 136-137 and Frank 2000, p. 548).

Comparison of ontological argument to cogito shows, however, that this directness and self-evidence does not have to be interpreted in any mystical way, even though such reading was sometimes suggested by Frank (Frank 1972, p. 137), and widely accepted by his later commentators (Obolevitch 2006, pp. 201-202; Aliaev 2009, p. 157; Obolevitch and Wszołek 2004, p. 39; Dushin 2014, p. 53; Obolevitch 
and Tsygankov 2017, p. 107; cf. however Antonov 2015, pp. 13-14). Frank's ontological proof, and likewise Descartes' cogito, is simply a performative utterance in which the speaker realizes, with a help of some additional premises, the necessary implications of their own existence.

Finally, I would like to draw attention to yet another consequence of the performative nature of the argument for God's existence, seemingly neglected by Frank and his commentators. Standard ontological proofs analyze the very notion of God, while Frank's argument starts with the existence of a thinking subject. Anselm's great discovery was that if God exists, its existence is necessary. A necessary being is understood as such that cannot not exist, that is, in the jargon of analytical philosophy, as a being that exists in every possible world. Frank clearly believed that his own argument also proves the existence of a logically necessary being. As he stated:

It is a primary or absolute necessity, both categorical and apodictical, combining factual irremovability with the logical indispensability. Such is the necessity of being as all-encompassing all-unity, as absolute fullness of everything that exists and can be thought, that is, in other words, the necessity of the Absolute (Frank 1972, p. 122).

Hence God, to which the ontological argument led, was supposed to be "a logically necessary fact, namely a reality which cannot be not thought of, or, which is the same, the content which cannot be thought as unreal" (Frank 2000, p. 551). However, it seems that the necessity at which Frank's ontological argument arrives is of a different nature to the necessity of traditional ontological proof. The necessity of Frank's argument is like the necessity of cogito, of which it is an extension. However, cogito is not-as I indicated-logically necessary, but only pragmatically. For the existence of Descartes is accidental, although when he negates it, he falls into inconsistency. Likewise, Frank's ontological proof concerns necessity only in the pragmatic sense. Therefore, God is necessary only due to the existence of man. In other words, the argument proves the existence of God only in those worlds in which I exist.

Paradoxically, this is not a charge against Frank's proof. This is only because this modification of his argument is not a subject of standard criticism of ontological proofs. For Kant's objection concerned logical necessity and here we have pragmatic necessity. Furthermore, the existence of God is not inferred from a mere concept but rather from the existence of the thinking subject. Frank's ontological argument may therefore be weaker, since it does not prove the absolute necessity of God's existence, but at the same time and for the same reasons is stronger than traditional ontological arguments, since it is at least logically correct.

\section{Conclusions}

Semen Frank generally opposed constructing arguments for God's existence. To him, the only source of faith should be religious experience. Allegedly, he wanted to write a book Religion within the Bounds of Bare Experience, which was supposed to be a reply to Kant's Religion within the Bounds of Bare Reason (Obolevitch and 
Tsygankov 2017, p. 111). According to Frank, rational proofs of God's existence were in general impossible, redundant and dangerous. For involving God in causal relations threatens to reduce God to our earthly categories. Frank was also apprehensive about using, in relation to God, the category of being or subject, which are not adequate for God's "supra-existent reality" (Frank 1983, p. 212). To Frank, Western onto-theology, rationally justifying religious truths, was therefore not an ally but a threat to true faith.

Frank's attitude was quite typical for Russian religious thought. As I have argued elsewhere, Russian philosophers, instead of a program of "philosophical theology", i.e. a project of justifying religious propositions rationally, typical for the West, proposed a program of "theological philosophy", which was about interpreting the world in the light of Christian revelation (Rojek 2016). This general attitude is also visible in the relation of Frank's work to traditional arguments for the existence of God. As Teresa Obolevitch has noted:

Frank implies that the direction of argument should be changed. One should head not from the analysis of particular beings to showing the existence of God, but just the opposite-starting from the fundamental statement of God's reality, justify the existence and possibility of cognition of things participating in God (Obolevitch 2006, p. 194).

Quite surprisingly, however, Frank made an exception for ontological proof. Not only did he not renounce the argument, but he also widely commented upon and creatively developed it in his writings. There is no inconsistency here, since in his opinion, this proof fundamentally differs from other arguments for the existence of God. Frank supposed that it is in fact not an inference but rather pointing to Absolute being.

Here is neither possible nor impossible to prove anything. The only thing that is possible is to show: to point the way to the direct discernment what is sought... Such is the true intent of the "ontological proof"; and therefore this "proof"... is the only philosophical argument that at least moves on the right path to the goal (Frank 1983, p. 216).

However, as I have shown, Frank's ontological argument is not such a simple act of intuition as it sometimes seemed to him and to his commentators. The proof has a logical structure which is a combination of indubitable cogito and the strong premise of the world dependency on the Absolute. While cogito endows the conclusion with certitude, the additional premise guarantees an achievement of God's existence. Yet the premise is so strong that it can be simply regarded as an expression of primary conviction about God's existence. As a result, Frank's ontological argument seems to be in fact not a rational justification of God's existence, but rather an explanation of the relation of the world to God. In this sense, it fits perfectly with the Russian program of theological philosophy. As Obolevitch continued:

In "empirical" arguments, the idea of God... is inferred on the basis of visible things, while ontological proofs accept from the onset the existence of God as the source of all other beings. In the former case, according to Frank, an inva- 
lid leap is made from imperfect things of this world to the divine sphere; in the latter, it is rather the Absolute that justifies particular beings (Obolevitch 2006, p. 197).

Ultimately, Frank's ontological argument turns out to be, like his whole philosophy, an attempt at a rational explanation, and not a justification, of one's own faith. Such a view also agrees with the intriguing story that Frank revealed to his son before death. After all, the mysterious voice which gave him the idea for a new version of ontological proof did not have to convince him about its own existence.

Acknowledgements This publication was generously supported by a grant from the National Science Center, Poland, No. 2014/15/B/HS1/01620. I am grateful to Katarzyna Kijania-Placek, Teresa Obolevitch and Marcin Suskiewicz as well as Jeremy Pilch, Katarzyna Popowicz and Walter Sisto for their comments and help.

Open Access This article is distributed under the terms of the Creative Commons Attribution 4.0 International License (http://creativecommons.org/licenses/by/4.0/), which permits unrestricted use, distribution, and reproduction in any medium, provided you give appropriate credit to the original author(s) and the source, provide a link to the Creative Commons license, and indicate if changes were made.

\section{References}

Aliaev, G. E. (2009). Dekartovskoe cogito kak ontologicheskoe dokazatel'stvo v sisteme absoliutnogo realizma S. L. Franka. In V. A. Friauf (Ed.), Dukhovnyi kontinent russkoi filosofii. Sbornik nauchnykh statei (pp. 150-159). Saratov: Saratovskii istochnik.

Anselm. (2007). Basic writings. Transl. by Th. Williams. Indianapolis: Hackett Publishing Company.

Antonov, K. M. (2015). Problematika filosofii religii v "bol'shoj trylogii” S. L. Franka: Predmet znaniia, Dusha cheloveka, Dukhovnye osnovy obshchestva. In K. M. Antonov (Ed.), Samyi vydaiushchiisia russkii filosof: Filosofiia religii i politiki S. L. Franka: Sbornik nauchnykh statei (pp. 12-22). Moscow: Izdatel'stvo PSTGU.

Augustyn, L. (2003). Myślenie z wnętrza objawienia. Studium filozofii Siemiona L. Franka. Krakow: Wydawnictwo Uniwersytetu Jagiellońskiego.

Ayer, A. J. (1953). Cogito, ergo sum. Analysis, 14, 27-31.

Bochenski, J. M. (2000). The five ways. In A. García de la Sienra (Ed.), The rationality of theism (pp. 61-92). Atlanta, GA: Rodopi.

Boobbyer, P. (1995). S. L. Frank: The life and work of a Russian Philosopher 1877-1950. Athens, OH: Ohio University Press.

Chernaia, E. G. (1993). Kartezianskoe cogito v semantike vozmozhnykh mirov. In N. D. Arutiunova \& N. K. Riabtseva (Eds.), Logicheskii analiz iazyka. Mental'nye deistviia (pp. 160-164). Moscow: Nauka.

Chizhevskii, D. S. (1954). L. Frank kak istorik filosofii i literatury. In V. Zen'kovskii (Ed.), Sbornik pamiati Semena Liudvigovicha Franka (pp. 157-174). München.

Descartes, R. (2006). Meditations, objections, and replies. Transl. by R. Ariew \& D. Cress. Indianapolis: Hackett Publishing Company.

Dobieszewski, J. (2012). Siemion Frank o dowodzie ontologicznym. Absolut i historia. W kręgu myśli rosyjskiej (pp. 196-206). Kraków: Universitas.

Dushin, O. Ė. (2014). “Ontologicheskii” argument v interpretatsii S. L. Franka. Mysl', 16, 47-54.

Ehlen, P. (2009). Russische Religionsphilosophie im 20. Jahrhundert: Simon L. Frank. FreiburgMünchen: Karl Alber Verlag.

Feldman, F. (1973). On the performatory interpretation of the cogito. The Philosophical Review, 82(3), 345-363.

Frank, S. L. (1972). Ontologicheskoe dokazatel'stvo bytiia Boga. Po tu storonu pravogo i levogo (pp. 107-151). Paris: YMCA Press. 
Frank, S. L. (1983). The unknowable. An ontological introduction to the philosophy of religion. Transl. by B. Jakim. Athens, OH: Ohio University Press.

Frank, S. L. (2000). Predmet znaniia. Minsk, Moscow: Harvest, AST.

Frank, S. L. (2017). Dokazatel'stvo bytiia Boga. Filosofskii zhurnal, 10(1), 89-98.

Hartshorne, Ch. (1967). What did Anselm discover? In J. Hick \& A. C. McGill (Eds.), The many-faced argument (pp. 321-333). New York: Macmillan.

Hintikka, J. (1962). Cogito ergo sum: Inference or performance? The Philosophical Review, 71, 3-32.

Hintikka, J. (1963). Cogito ergo sum as an inference and performance. The Philosophical Review, 72, 487-496.

Hintikka, J. (2000). Cogito, ergo quis est? Revue de Métaphysique et de Morale, 1, 13-28.

Il'in, V. N. (1954). Nikolai Kuzanskii i S. L. Frank. In V. Zen'kovskii (Ed.), Sbornik pamiati Semena Liudvigovicha Franka (pp. 85-116). Munchen.

Kotsiuba, V. I. (2001). K voprosu ob ontologicheskom dokazatel'stve (S. L. Frank-I. Kant). In N. N. Trubnikova, et al. (Eds.), Znanie $i$ traditsiia $v$ istorii mirovoi filosofii (pp. 397-412). Moscow: ROSSPE்N.

Lewis, D. (1970). Anselm and Actuality. Nô̂s, 4, 175-188.

Lichtenberg, G. Ch. (2012). Philosophical writings. Transl. by S. Tester. Albany, NY: State University of New York Press.

Łukasiewicz, J. (1938). Kartezjusz. Kwartalnik Filozoficzny, 15, 123-128.

Malcolm, N. (1960). Anselm's ontological arguments. Philosophical Review, 69(1), 41-62.

Nakhnikian, G. (1969). On the logic of cogito propositions. Noûs, 3(2), 197-209.

Obolevitch, T. (2006). Pragmatyczny konkordyzm. Wiara i wiedza w myśli Włodzimierza S. Sołowjowa $i$ Siemiona L. Franka. Kraków, Tarnów: OBI, Biblos.

Obolevitch, T. (2007). Ontologizm, czyli Siemiona Franka polemika z pokantowskim epistemologizmem. Roczniki Filozoficzne, 55(2), 67-79.

Obolevitch, T., \& Sajdek, Z. (2011). Ontologizm i dowód ontologiczny w filozofii rosyjskiej. In S. Wszołek (Ed.), Dowody ontologiczne. W 900. rocznicę śmierci św. Anzelma (pp. 169-185). Kraków: Copernicus Center Press.

Obolevitch, T., \& Tsygankov, A. S. (2017). Filosofiia religii S. L. Franka v svete novykh materialov. Filosofskii zhurnal, 10(1), 99-115.

Obolevitch, T., \& Wszołek, S. (2004). Dowód ontologiczny w ujęciu Siemiona L. Franka. Analecta Cracoviensia, 36, 35-47.

Oppy, G. (2006). Arguing about Gods. Cambridge: Cambridge University Press.

Plantinga, A. (1974). The nature of necessity. Oxford: Oxford University Press.

Rapaport, W. J. (1976). On 'cogito' propositions. Philosophical Studies, 29(1), 63-68.

Rojek, P. (2003). Czy “myślę więc jestem”? Principia, 34, 185-194.

Rojek, P. (2011). Argumenty ontologiczne Hegla. In S. Wszołek (Ed.), Dowody ontologiczne. W 900. rocznicę śmierci św. Anzelma (pp. 151-168). Kraków: Copernicus Center Press.

Rojek, P. (2016). Post-secular metaphysics: Georges Florovsky's project of theological philosophy. In A. Mrówczyński-Van Allen, T. Obolevitch, \& P. Rojek (Eds.), Beyond modernity: Russian religious philosophy and post-secularism (pp. 97-135). Eugene, OR: Pickwick Publications.

Russell, B. (1905). On denoting. Mind, 14(56), 479-493.

Scholz, H. (1931). Über das Cogito, ergo sum. Kant-Studien, 36, 126-147.

Slezak, P. (2010). Doubts about Descartes' indubitability: The cogito as intuition and inference. Philosophical Forum, 41(4), 389-412.

Sobel, J. H. (2004). Logic and theism. Cambridge: Cambridge University Press.

Solov'ev, V. S. (1988). Dostovernost' razuma. Sochineniia v dvukh tomakh (Vol. 1, pp. 758-797). Moscow: Mysl'.

Szatkowski, M. (Ed.). (2012). Ontological proofs today. Frankfurt: Ontos Verlag.

Weinberg, J. R. (1962). Cogito, Ergo sum: Some reflections on Mr. Hintikka's Article. Philosophical Review, 71(4), 483-491.

Wojciechowski, E. (1987). W sprawie Kartezjańskiego "Cogito, ergo sum”. Ruch Filozoficzny, 44, 292-298.

Zelinsky, V. (2015). The God of philosophers or the other God? Faith and knowledge in the philosophy of the later Frank. In T. Obolevitch \& P. Rojek (Eds.), Overcoming the secular. Russian religious philosophy and post-secularism (pp. 115-131). Krakow: Pontifical University of John Paul II Press. 
Publisher's Note Springer Nature remains neutral with regard to jurisdictional claims in published maps and institutional affiliations. 